\title{
CONTINUOUS ETHANOL PRODUCTION USING IMMOBILIZED YEAST CELLS ENTRAPPED IN LOOFA- REINFORCED ALGINATE CARRIERS
}

\author{
Phoowit Bangrak $^{1}$, Savitree Limtong ${ }^{2}$, Muenduen Phisalaphong ${ }^{1 *}$ \\ ${ }^{1}$ Department of Chemical Engineering, Faculty of Engineering, Chulalongkorn University, Bangkok 10330, Thailand; \\ ${ }^{2}$ Department of Microbiology, Faculty of Science, Kasetsart University, Bangkok 10900, Thailand.
}

Submitted: February 22, 2010; Approved: January 13, 2011.

\begin{abstract}
A culture of Saccharomyces cerevisiae M30 entrapped in loofa-reinforced alginate was used for continuous ethanol fermentation in a packed-bed reactor with initial sugar concentrations of 200-248 g/L. Maximum ethanol productivity of $11.5 \mathrm{~g} /(\mathrm{L} \cdot \mathrm{h})$ was obtained at an ethanol concentration of $57.4 \mathrm{~g} / \mathrm{L}$, an initial sugar concentration of $220 \mathrm{~g} / \mathrm{L}$ and a dilution rate (D) of $0.2 \mathrm{~h}^{-1}$. However, a maximum ethanol concentration of $82.1 \mathrm{~g} / \mathrm{L}$ (productivity of $9.0 \mathrm{~g} /(\mathrm{L} \cdot \mathrm{h})$ ) was obtained at a $\mathrm{D}$ of $0.11 \mathrm{~h}^{-1}$. Ethanol productivity in the continuous culture was 6-8-fold higher than that in the batch culture. Due to the developed carrier's high biocompatibility, high porosity, and good mechanical strength, advantages such as cell regeneration, reusability, altered mechanical strength, and high capacity to trap active cells in the reactor were achieved in this study. The immobilized cell reactor was successfully operated for 30 days without any loss in ethanol productivity. The average conversion yield was 0.43-0.45 throughout the entire operation, with an immobilization yield of $47.5 \%$. The final total cell concentration in the reactor was $37.3 \mathrm{~g} / \mathrm{L}(17.7 \mathrm{~g} / \mathrm{L}$ immobilized cells and $19.6 \mathrm{~g} / \mathrm{L}$ suspended cells). The concentration of suspended cells in the effluent was $0.8 \mathrm{~g} / \mathrm{L}$.
\end{abstract}

Key words: ethanol, loofa, alginate, immobilization, continuous

\section{INTRODUCTION}

Ethanol demand has continued to grow, both as an alternative fuel and as a petroleum fuel extender because of gasoline shortages. Ethanol production from renewable carbohydrate materials has attracted worldwide interest, and much research has focused on ethanol production using immobilized viable microbial cells in continuous systems. Continuous fermentation using immobilized cell (IC) carriers offers many advantages, such as higher productivity, relative ease of product separation, biocatalyst reuse, and high productivity. The immobilization of yeast cells inside the porous support material enhances cell stability (5).

Fermentative ethanol production by $S$. cerevisiae immobilized within alginate beads has been found to have a higher productivity than in a batch system (8). However, some limitations, such as gel degradation, low physical strength and severe mass transfer restrictions, were often observed when using alginate-based carriers. Dias et al. (3) reported a lower specific growth rate of immobilized yeast cells due to oxygen 
diffusion problems caused by entrapment in a Ba-alginate gel. In contrast, the loofa sponge was shown to be an excellent cell carrier for ethanol fermentation by flocculating the cells in a bubble column with an external loop for the recirculation of the fermentation broth (11). Its strength, abundance, low price, biodegradability, and natural origin are of great interest. However, a low-shear environment and a large aggregate of cells were required during the application of the loofa sponge to prevent excessive cell sloughing from the carrier $(9,10)$. In our previous study, immobilized yeast cells entrapped in loofareinforced alginate matrix (ALM) carriers were successfully developed for repeated batch ethanol fermentations in a 500$\mathrm{mL}$ shake flask system (13). The carriers were simply fabricated by gelating a peripheral loofa sponge that had been previously dipped in an alginate/cell mixture. An ALM with dimensions of $9 \times 9 \times 3 \mathrm{~mm}^{3}$, which was comparable to a $2-\mathrm{mm}$ diameter alginate bead, was found to be effective for yeast immobilization. Moreover, after storage for 4 months, the ALM-immobilized cell culture was still active, and the stability of IC cultures in the ALM was higher than that of the suspended culture (13). The ALM structure proved to be more porous and less dense than a typical alginate bead, allowing for better internal mass-transfer diffusion. The aim of present investigation is to use an ALM carrier with dimensions of $20 \times 20 \times 3 \mathrm{~mm}^{3}$ for continuous ethanol fermentation in a packedbed reactor (PBR) and evaluate its performance for long-term operation.

\section{MATERIALS AND METHODS}

\section{Microorganisms and media}

Saccharomyces cerevisiae M30 was selected for this study because of its high efficiency in ethanol production from molasses at high temperatures. Starter cultures were prepared by transferring cells from stock PDA slants to $150 \mathrm{~mL}$ of sterilized medium followed by incubation at $33^{\circ} \mathrm{C}$ at $150 \mathrm{rpm}$ for $20 \mathrm{~h}$. The medium for the starter culture contained $0.05 \%$ ammonium sulfate and 5\% inverse sugar from palm sugar at
$\mathrm{pH}$ 5.0. Subsequently, the resulting cell suspension was concentrated by decantation and then transferred to the main culture.

\section{Cell immobilization}

Sodium alginate $(3 \% \mathrm{w} / \mathrm{v})$ solution was formulated by dissolving $\mathrm{Na}$-alginate powder in $0.9 \%$ (w/v) $\mathrm{NaCl}$ solution. It was autoclaved for $5 \mathrm{~min}$ at $121^{\circ} \mathrm{C}$ and stored overnight at $4^{\circ} \mathrm{C}$ to facilitate deaeration. To form an alginate-cell mixture, $5 \mathrm{~mL}$ of cell suspension was added to $50 \mathrm{~mL}$ of $3 \%(\mathrm{w} / \mathrm{v})$ alginate solution. Loofa sponges were cut into small thin square pieces with dimensions of $19 \times 19 \times 2 \mathrm{~mm}^{3}$ using scissors. To form ALMs, $2 \mathrm{~g}$ of sterilized thin square loofa sponges were dipped into the alginate/cell mixture. The gel carriers were transferred to $1.5 \%(\mathrm{w} / \mathrm{v}) \mathrm{CaCl}_{2}$ solution and left to harden in this solution with mild stirring for $15 \mathrm{~min}$. The carriers were then rinsed 3 times with $0.9 \%(\mathrm{w} / \mathrm{v}) \mathrm{NaCl}$ solution. The carriers were prepared under aseptic conditions, and the average ALM dimensions were $20 \times 20 \times 3 \mathrm{~mm}^{3}$.

\section{Fermentations}

A 1-L $(\varnothing=5.7 \mathrm{~cm}$; height $=43.4 \mathrm{~cm})$ reactor column containing an immobilized cell bed of ALM carriers was used for the study. The experimental setup for the PBR with a packed volume of $32 \%(\mathrm{v} / \mathrm{v})$ of the total bed volume is shown in Fig. 1. The temperature of the system was controlled at $32 \pm$ $1^{\circ} \mathrm{C}$ by passing $28^{\circ} \mathrm{C}$ cooling water inside the reactor jacket. Initial sugar concentrations of 200, 220, and $240 \mathrm{~g} / \mathrm{L}$ were continuously fed into the bottom of the reactor at dilution rates of $0.11,0.16,0.20$, and $0.30 \mathrm{~h}^{-1}$. Samples $(5 \mathrm{~mL})$ were collected every 8 hours. The samples were frozen before determining the sugar, ethanol, and cell concentrations to enable simultaneous analysis of all samples.

\section{Analytical methods}

Free cell dry weight was determined from the absorbance measured at $660 \mathrm{~nm}$ by a UV-2450 UV-visible spectrophotometer and converted to dry cell concentration 
using a corresponding standard curve. For immobilized cells, a known mass of cell carriers was dissolved in $0.05 \mathrm{M}$ sodium citrate. After the sponge was removed, immobilized cell concentrations were determined in a manner similar to that used for the free cells. Yeast cell viability was determined using methylene blue staining (2). The concentration of ethanol was determined using a gas chromatograph (model GC-7AG; Shimadzu, Kyoto, Japan) equipped with a flame ionization detector. To measure reducing sugar concentration, the sample solution was hydrolyzed in $33 \% \mathrm{HCl}$ at $100^{\circ} \mathrm{C}$ for $10 \mathrm{~min}$ and neutralized with $\mathrm{NaOH}$ solution. Reducing sugar content was then determined using the dinitrosalicylic acid method (6).

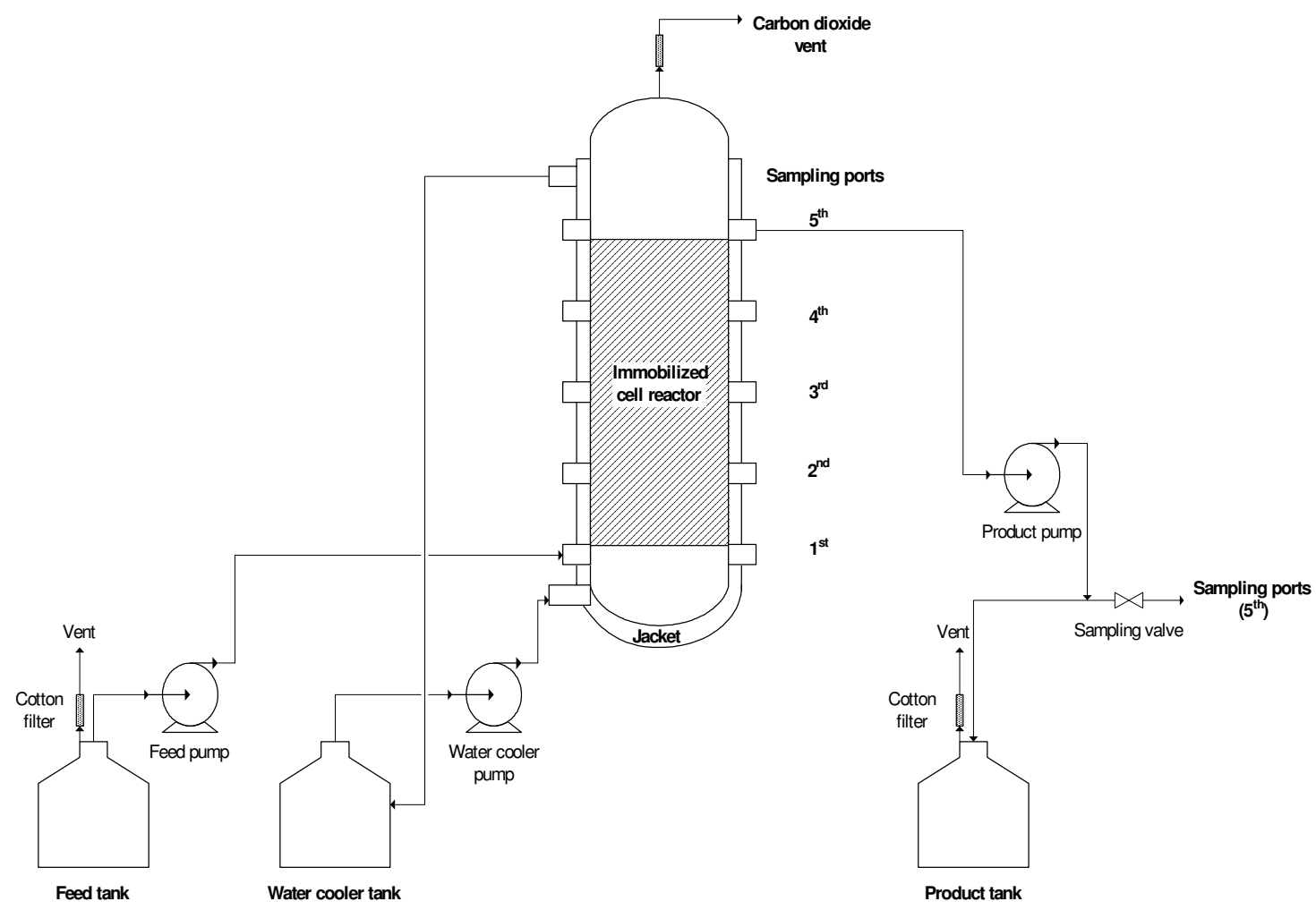

Figure 1. Schematic diagram of the immobilized-cell PBR.

\section{RESULTS}

\section{Batch fermentation}

The purpose of this work was to expand upon our previous work (13) and develop an efficient, continuous process for producing ethanol from sugarcane molasses using an immobilized S. cerevisiae M30 culture. ALM was chosen based on its strong potential as a cell carrier. The ALM carrier has many advantages, including high regeneration ability, reusability, altered mechanical strength, and high ethanol productivity. Inspection of the cross section of the ALM carrier (Fig. 2) reveals the carrier's structure, which is composed of loofa fiber, a layer of alginate gel, and a hollow space between the loofa fiber and alginate gel. The hollow space between the alginate and loofa fiber was found to be an ideal space for cell growth (13). Fig. 3 and 4 reveals that yeasts can also grow well in the alginate layer and in the hollow space of the core fiber. The cells had a normal oval shape, and filaments were 
observed connecting cells both to other cells and to cellulose fibers (Fig. 4). This filamentous structure likely promoted firm attachment of the cells both to the carrier and to cell aggregations.

For more convenient preparation, the ALM carrier used in the PBR was modified into a square with dimensions of $20 \mathrm{x}$ $20 \times 3 \mathrm{~mm}^{3}$. Pre-examination was performed in $500-\mathrm{mL}$ Erlenmeyer flasks containing $250 \mathrm{~mL}$ sterilized medium under controlled conditions of $220 \mathrm{~g} / \mathrm{L}$ of initial sugar, initial $\mathrm{pH}$ of
$5.0,150 \mathrm{rpm}$, and $33^{\circ} \mathrm{C}$. Ethanol production, growth rate, and immobilized yield $\left(\mathrm{Y}_{\mathrm{I}}\right)$ using the squares with dimensions of 20 x $20 \times 3 \mathrm{~mm}^{3}$ and $9 \times 9 \times 3 \mathrm{~mm}^{3}$ were comparable (Fig. 5). An ethanol concentration of $89-90 \mathrm{~g} / \mathrm{L}$ was produced within 60 hours of batch fermentation, whereas the IC and free-cell concentrations were about $4.0 \mathrm{~g} / \mathrm{L}$ and $1.0 \mathrm{~g} / \mathrm{L}$, respectively. No significant differences were observed in the data obtained from the ALM carriers of the two different sizes.

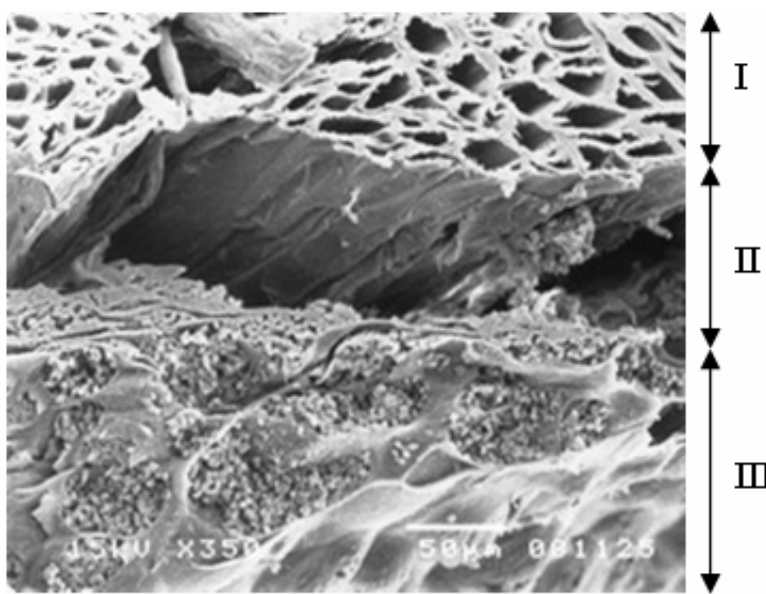

(A)

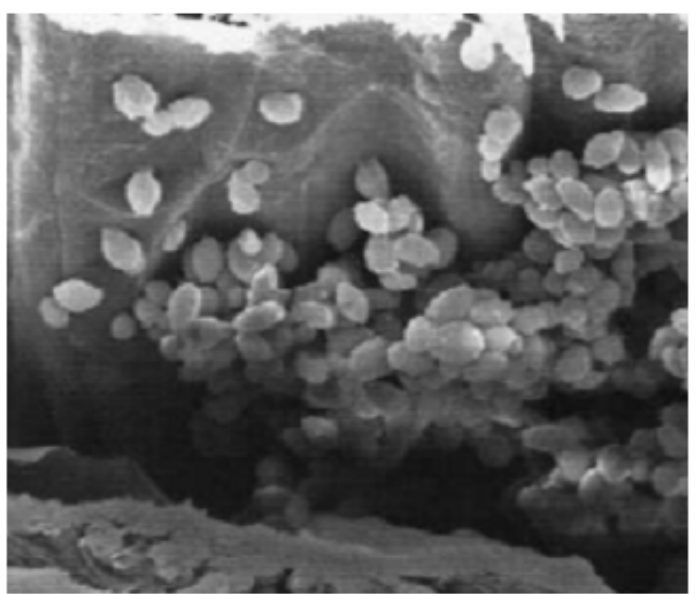

(B)

Figure 2. (A) Cross-section of the ALM after $72 \mathrm{~h}$ of ethanol fermentation. The ALM consisted of loofa fiber (I), a hollow space between the loofa fiber and alginate gel (II), and alginate gel (III). (B) A higher-magnification view of the hollow space.

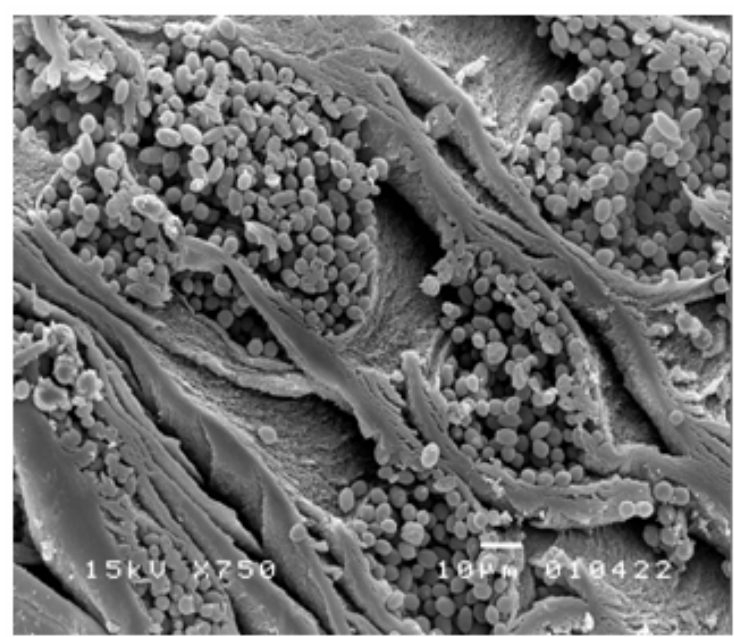

$\mathbf{X} 750$

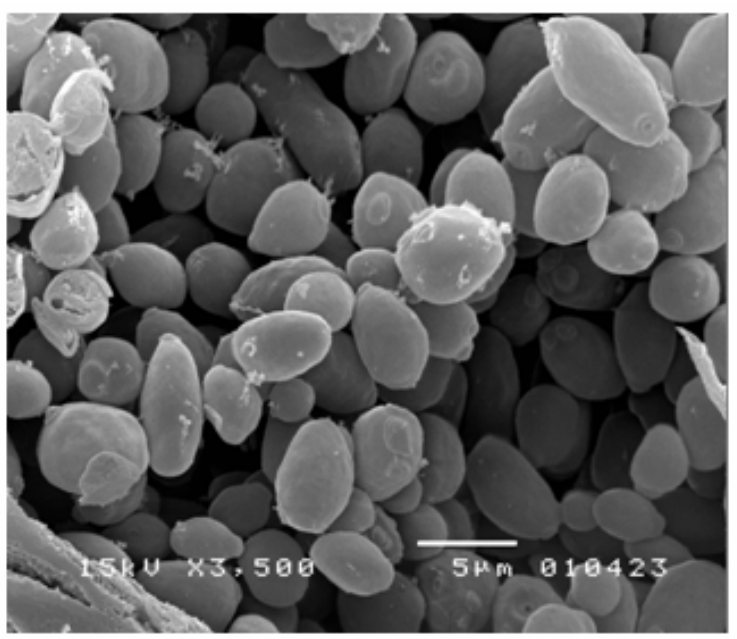

X 3,500

Figure 3. Yeast cells in the alginate gel layer of the ALM after $72 \mathrm{~h}$ of ethanol fermentation 


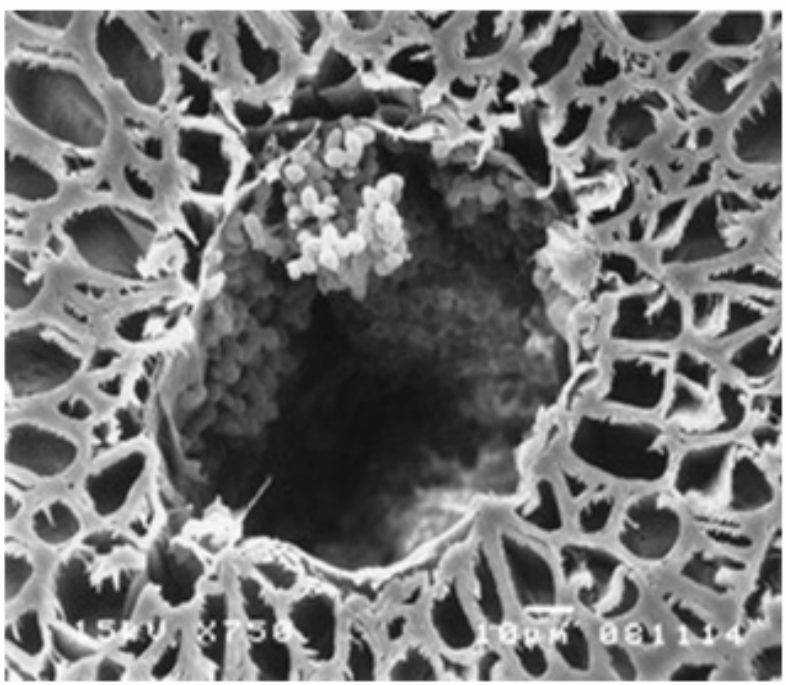

$\mathbf{X} 750$

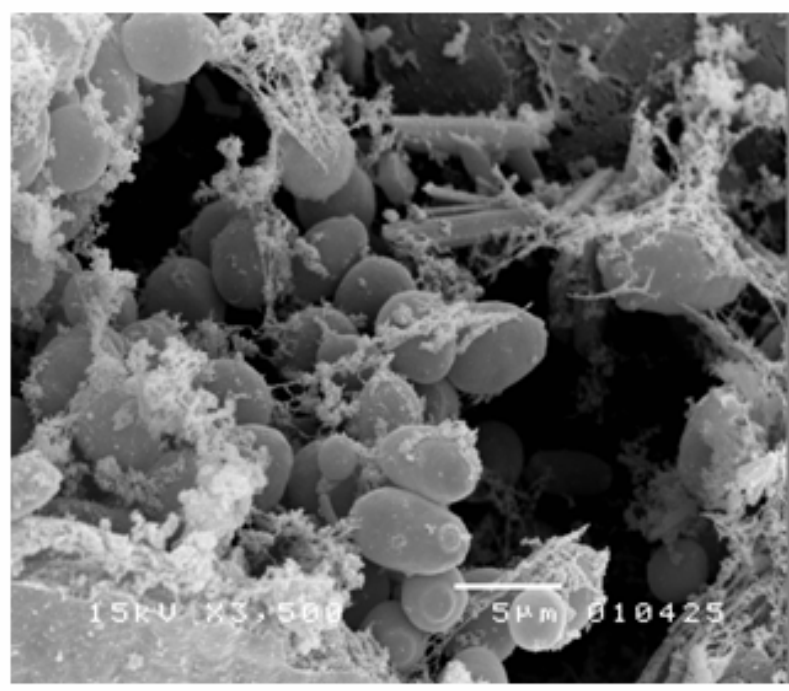

X 3,500

Figure 4. Yeast cells in the hollow core fibers of the ALM after $72 \mathrm{~h}$ of ethanol fermentation.

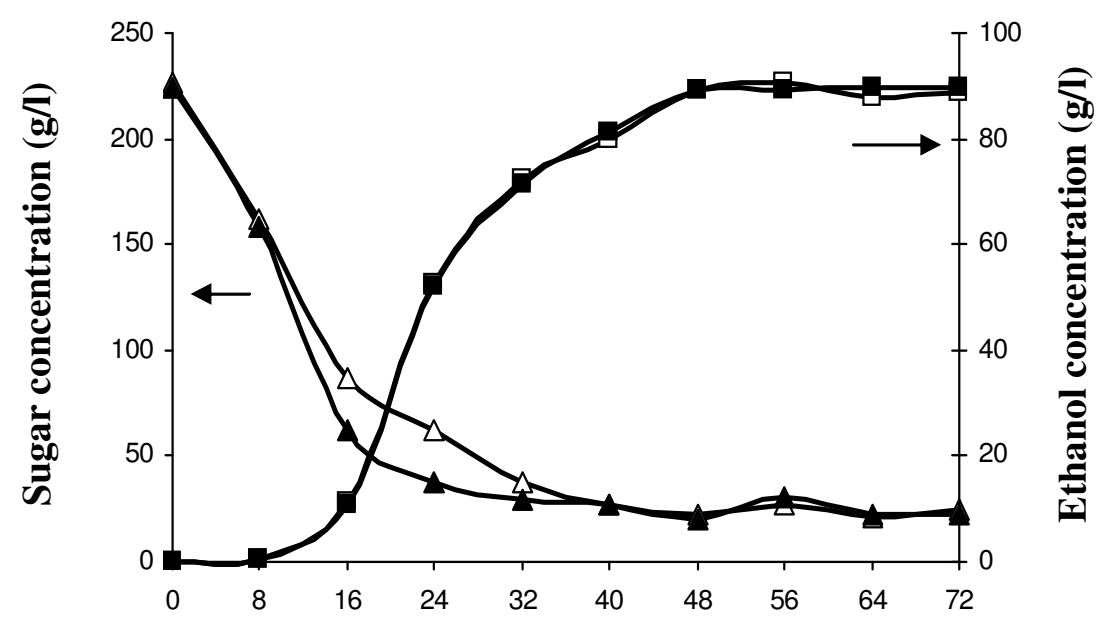

Time (h)

Figure 5. Batch fermentations using ALM carriers with dimensions of $9 \times 9 \times 3 \mathrm{~mm}^{3}$ (open symbols) and $20 \times 20 \times 3 \mathrm{~mm}$ (filled symbols); $\Delta, \mathbf{\Delta}=$ sugar: $\square, \boldsymbol{\square}=$ ethanol.

\section{Continuous fermentation}

\section{Effect of dilution rate and initial sugar concentration:}

Continuous ethanol fermentations using cane molasses in a 1-L packed-bed reactor were performed at a temperature of $32 \pm$ $1^{\circ} \mathrm{C}$ and an initial $\mathrm{pH}$ of 5.0. The initial reducing sugar concentrations were 202, 222, and $248 \mathrm{~g} / \mathrm{L}$ at dilution rates ranging from $0.11-0.30 \mathrm{~h}^{-1}$. The effects of dilution rate on ethanol concentration and ethanol productivity are presented in Fig. 6 and Fig. 7, respectively. The ethanol concentration decreased as the dilution rate increased, as is 
commonly observed. When the initial sugar concentration $\left(\mathrm{S}_{0}\right)$ was at 200-220 g/L, the ethanol productivity increased linearly with the dilution rate, from 0.1 to $0.2 \mathrm{~h}^{-1}$, and then remained nearly constant. However, at the very high initial sugar concentration of $248 \mathrm{~g} / \mathrm{L}$, the ethanol productivity was limited to $8.0 \mathrm{~g} /(\mathrm{L} \cdot \mathrm{h})$. The optimal $\mathrm{S}_{0}$ for ethanol productivity was 220 $\mathrm{g} / \mathrm{L}$. Under steady-state conditions and at varying dilution rates of $0.11,0.16,0.20$ and $0.30 \mathrm{~h}^{-1}$, the average ethanol concentrations in the effluent were 82.1, 66.1, 57.4 and 37.2 $\mathrm{g} / \mathrm{L}$, respectively, corresponding to ethanol productivities $\left(\mathrm{P}_{\mathrm{E}}\right)$ of 9.0, 10.6, 11.5 and $11.2 \mathrm{~g} /(\mathrm{L} \cdot \mathrm{h})$, respectively. The ethanol conversion yield $\left(\mathrm{Y}_{\mathrm{E} / \mathrm{S}}\right)$ was almost constant at $0.45 \pm 0.02$. An optimal ethanol productivity of $11.5 \mathrm{~g} /(\mathrm{L} \cdot \mathrm{h})$ was obtained at an ethanol concentration of $57.4 \mathrm{~g} / \mathrm{L}$, an initial sugar concentration of $220 \mathrm{~g} / \mathrm{L}$, and $\mathrm{D}$ of $0.2 \mathrm{~h}^{-1}$, whereas the maximum ethanol concentration of $82.1 \mathrm{~g} / \mathrm{L}\left(\mathrm{P}_{\mathrm{E}}=9.0 \mathrm{~g} /(\mathrm{L} \cdot \mathrm{h})\right)$ was obtained at a $\mathrm{D}$ of $0.11 \mathrm{~h}^{-1}$. At the end of the procedure $(360 \mathrm{~h})$, the concentrations of immobilized cells, suspended cells in the reactor, and suspended cells in the effluent were $16.0 \pm 0.4$, $12.3 \pm 0.5$ and $0.6 \pm 0.1 \mathrm{~g} / \mathrm{L}$, respectively, with an average immobilized yield of $56.5 \%$.

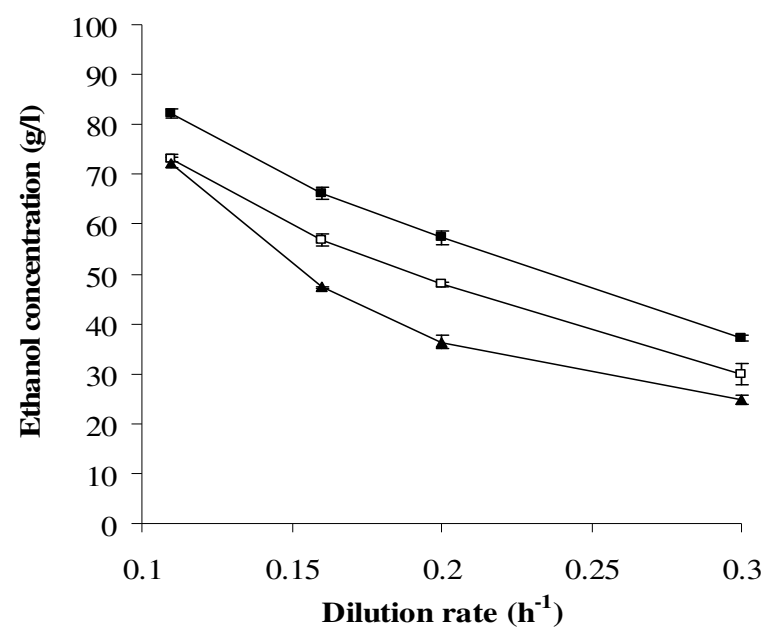

Figure 6. Ethanol concentration at dilution rates of $0.1-0.3 \mathrm{~h}^{-1}$ and initial sugar concentrations of $200 \mathrm{~g} / \mathrm{L}(\square), 220 \mathrm{~g} / \mathrm{L} \mathrm{( \square ),} \mathrm{and} 248$ $\mathrm{g} / \mathrm{L}(\boldsymbol{\Delta})$.

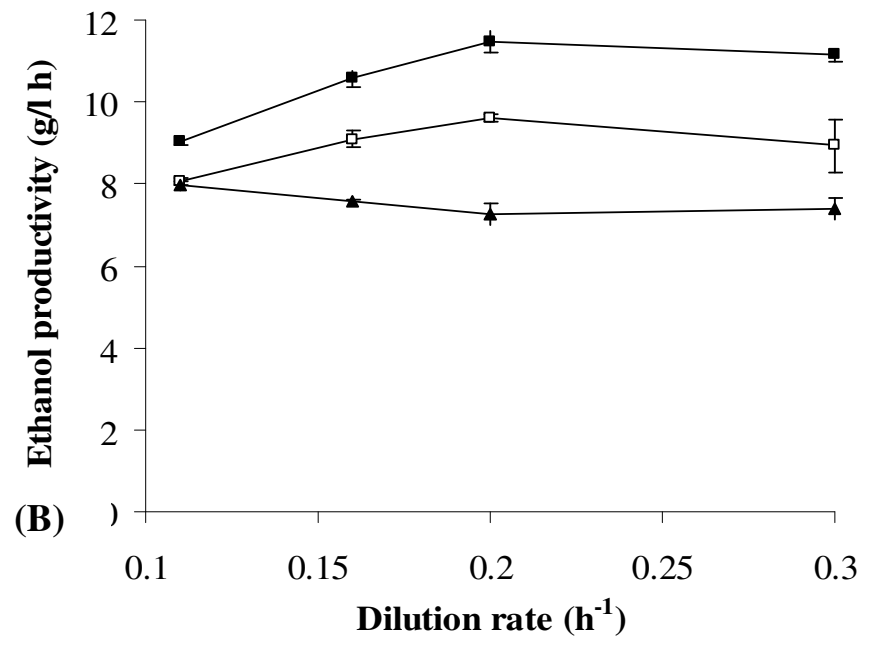

Figure 7. Ethanol productivity at dilution rates of $0.1-0.3 \mathrm{~h}^{-1}$ and initial sugar concentrations of $200 \mathrm{~g} / \mathrm{L}(\square), 220 \mathrm{~g} / \mathrm{L}(\mathbf{\square})$, and $248 \mathrm{~g} / \mathrm{L}(\boldsymbol{\Delta})$.

Effect of superficial velocity: The design of packing materials that achieve ideal conditions, which correspond to plug flow and a uniform distribution of fluid across the crosssection of the column, is important for a PBR. The ethanol and reducing sugar concentrations measured from the five sampling ports on both sides of the PBR after the system reached steady state revealed a satisfactorily uniform distribution of the fluid. The ethanol concentration profiles in a plug-flow reactor packed with immobilized cells entrapped in ALM are shown in Fig. 6. Usually, for anaerobic ethanol fermentation with high substrate concentrations, it is likely that external mass transfer is not limiting, at least for a large portion of the packed bed (15). The external mass transfer coefficient can be enhanced by increasing the liquid superficial velocity. In this study, the effect of liquid superficial velocity was examined. Liquid superficial velocity $\left.\left(\mathrm{V}_{\mathrm{S}}, \mathrm{cm} / \mathrm{h}\right)\right)$ was calculated from:

$$
V_{S}=\frac{Q}{\varphi A},
$$

where $\mathrm{Q}$ is the volumetric flow rate of the fluid $\left(\mathrm{cm}^{3} / \mathrm{h}\right), A$ is 
the cross-sectional area of the bed $\left(\mathrm{cm}^{2}\right)$, and $\varphi$ is the packedbed porosity (the volume of voids per volume of reactor).

Based on the results, the effect of superficial velocity on ethanol concentration profile can be divided into two subeffects, one with $\mathrm{S}_{0}$ of $200-220 \mathrm{~g} / \mathrm{L}$ and the other with $\mathrm{S}_{0}$ of 248 g/L. Fig. 8(A) and Fig. 8(B) depict the results with $S_{0}$ at $200 \mathrm{~g} / \mathrm{L}$ and $220 \mathrm{~g} / \mathrm{L}$, respectively. The results revealed an increase in ethanol concentration as the liquid superficial velocity was increased from $4.8 \mathrm{~cm} / \mathrm{h}$ to $6.9 \mathrm{~cm} / \mathrm{h}$. However, no significant enhancement in ethanol production was observed when the liquid superficial velocity was further increased to 8.7-13.0 cm/h. Based on the result with $S_{0}$ at $200-220 \mathrm{~g} / \mathrm{L}$, the external mass transfer resistance exhibited some negative effects on the overall fermentation rate of the packed bed reactor when the liquid creeping over the static solid particles had a velocity of less than about $7 \mathrm{~cm} / \mathrm{h}$. However, at a high initial sugar concentration at $\mathrm{S}_{0}$ of $248 \mathrm{~g} / \mathrm{L}$, decreases in sugar consumption and ethanol production were observed as the liquid superficial velocity increased (Fig. 8(C)). The inhibitory effects of high initial sugar and high ethanol concentrations have been previously reported (12). Therefore, mass transfer resistance had a positive effect on ethanol fermentation at very high sugar concentrations due to a reduction of sugar-induced inhibition.

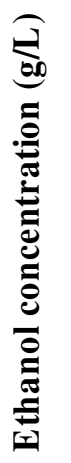

(A)

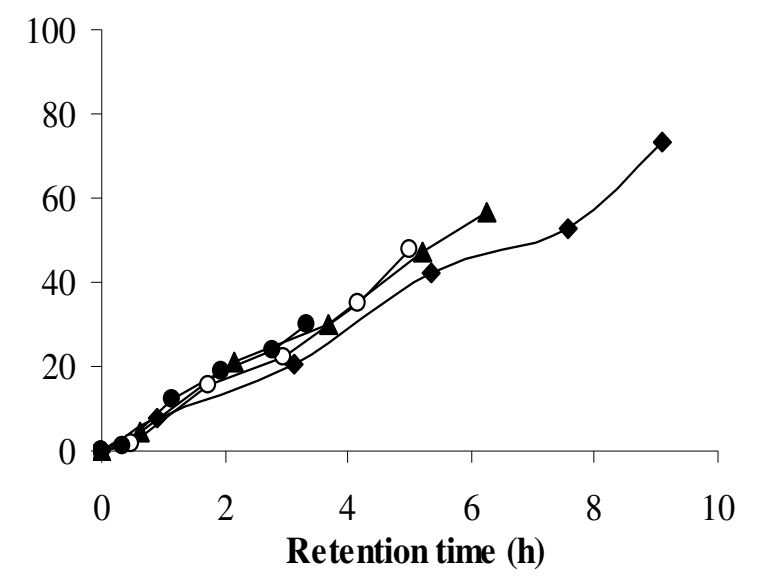

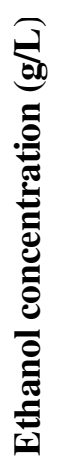

(B)

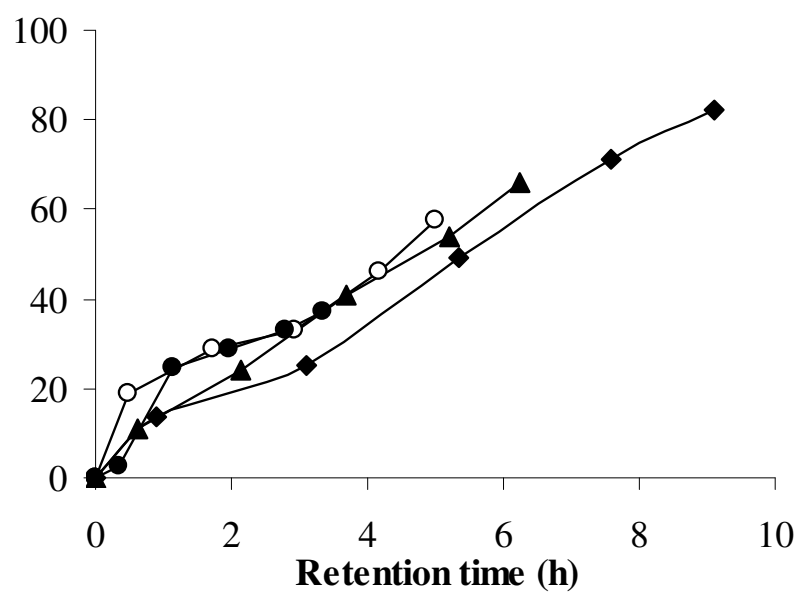

అ્త్ర0

(C)

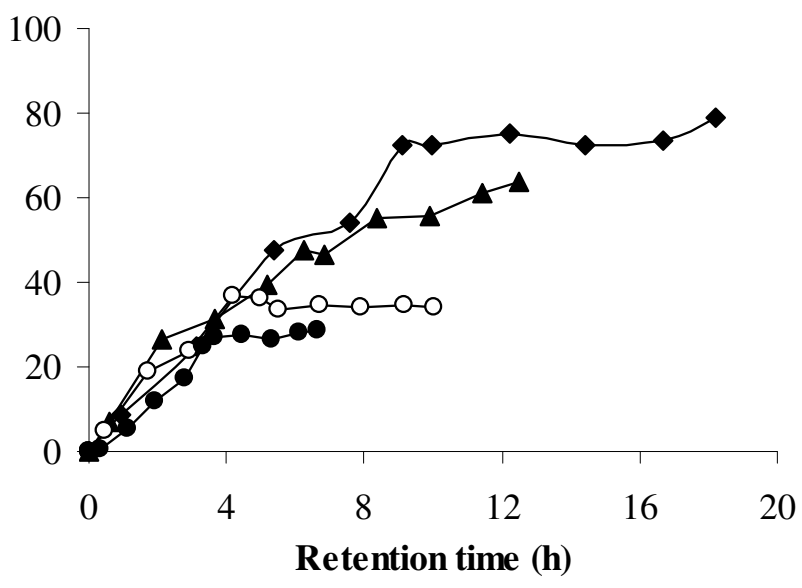

Figure 8. The steady-state ethanol concentration profiles at initial sugar concentrations of $200 \mathrm{~g} / \mathrm{L}$ (A), $220 \mathrm{~g} / \mathrm{L}$ (B), and $248 \mathrm{~g} / \mathrm{L}(\mathrm{C})$ and at superficial velocities of $4.8 \mathrm{~cm} / \mathrm{h}(\diamond), 6.9$ $\mathrm{cm} / \mathrm{h}(\boldsymbol{\Delta}), 8.7 \mathrm{~cm} / \mathrm{h}(\circ)$, and $13.0 \mathrm{~cm} / \mathrm{h}(\bullet)$.

Stability test: The long-term stability of the immobilized yeast cells entrapped in ALM carriers during continuous ethanol fermentation was examined using an initial sugar concentration of $220 \mathrm{~g} / \mathrm{L}$ at a constant D of $0.11 \mathrm{~h}^{-1}$. After 30 days of operation, the degradation of alginate films due to cell growth and $\mathrm{CO}_{2}$ production was observed and resulted in cell leakage. Such leaks could also be observed from the cell suspensions in the reactor and in the effluent. Fig. 9(A) and Fig. 9(B) depict the suspended yeasts in the reactor and in the 
effluent, respectively. The suspended cells in the reactor appeared healthy and retained their normal oval shape. In addition, aggregations of yeast cells with filamentous connections were observed. These cell filaments were barely observed in the alginate gel layer. Therefore, it is possible that the formation of these filaments may be activated by the cellulose fibers of the loofa sponge. It was found that almost all of the aggregated cells were trapped in the packed bed. However, the suspended cells in the effluent were thinner, much smaller, and non-aggregated. The use of a hemacytometer and methylene blue staining to discriminate between dead and live cells revealed that almost all of the cells $(>95 \%)$ in the reactor were alive, but more than $70 \%$ of cells in the effluent were dead.

The robust performance of the immobilized cells in the alginate-loofa cube during continuous ethanol fermentation in the PBR was confirmed by satisfactory operational stability during 30-day fermentation at a $\mathrm{D}$ of $0.11 \mathrm{~h}^{-1}$. There was no significant decline in productivity during continuous operation, and an average ethanol productivity of $8.7 \mathrm{~g} /(\mathrm{L} \cdot \mathrm{h})$ was achieved at an average ethanol concentration of $79.3 \mathrm{~g} / \mathrm{L}$. The average conversion yield was $0.43-0.45$ throughout the entire operation, with an immobilization yield of $47.5 \%$. The final total cell concentration in the reactor was $37.3 \mathrm{~g} / \mathrm{L}(17.7 \mathrm{~g} / \mathrm{L}$ immobilized cells and $19.6 \mathrm{~g} / \mathrm{L}$ suspended cells). The concentration of suspended cells in the effluent was $0.8 \mathrm{~g} / \mathrm{L}$.

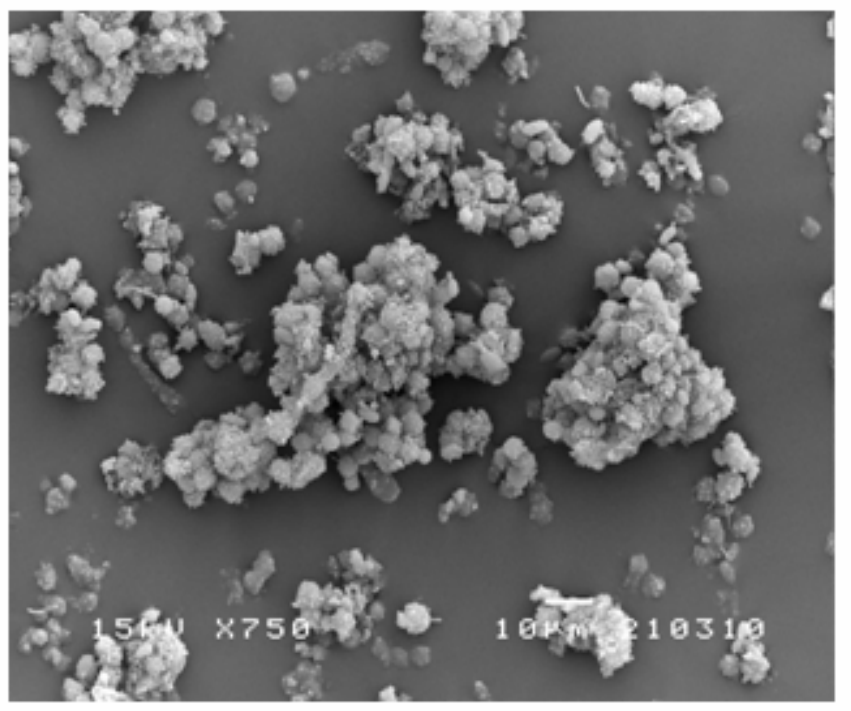

(A)
X 750

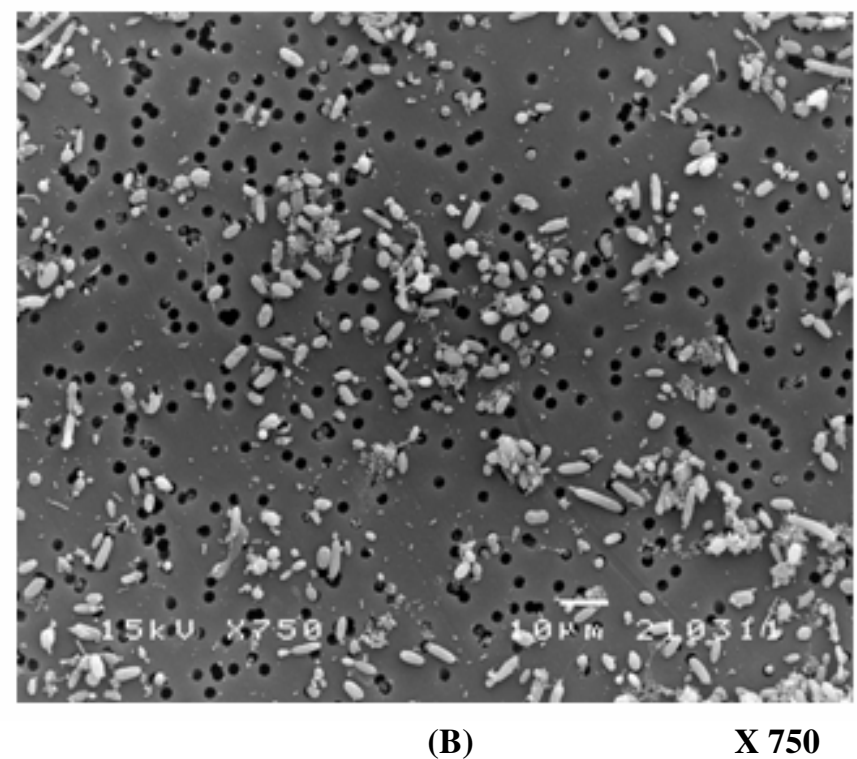

(B)

Figure 9. Suspended cells in the PBR (A) and in the effluent (B) after 30 days of continuous fermentation.

\section{DISCUSSION}

The data presented in this work demonstrate that continuous ethanol production from molasses using immobilized $S$. cerevisiae M30 cells entrapped in ALM $(20 \mathrm{x}$ $20 \times 3 \mathrm{~mm}^{3}$ ) is promising. Compared to the batch fermentation, higher ethanol productivity (6-8-fold) was obtained by continuous fermentation in the PBR. A maximum productivity of $11.5 \mathrm{~g} / \mathrm{L} \mathrm{h}$ at an ethanol concentration of $57.4 \mathrm{~g} / \mathrm{L}$ was obtained using an initial sugar concentration of $220 \mathrm{~g} / \mathrm{L}$ at a D of $0.20 \mathrm{~h}^{-1}$, whereas a maximum ethanol concentration of 82.1 $\mathrm{g} / \mathrm{L}$ was obtained at a $\mathrm{D}$ of $0.11 \mathrm{~h}^{-1}$. The steady-state ethanol 
concentration in the effluent of the packed-bed column obtained in this work was reasonably high compared to those described in previous reports $(1,4,7,8,14,16)$. The experimental results revealed that the ALM was suitable for yeast immobilization in a continuous PBR. With its favorable mechanical properties, high biocompatibility, and superior porous structure, the ALM is a system with high cell density, high ethanol production, and high stability. Furthermore, the ALM should be applied as a cell carrier for efficient production in other fermentation systems.

\section{ACKNOWLEDGEMENTS}

This work was supported by the Thailand Research Fund (TRF) and Chulalongkorn University (contract grant number RSA5080011).

\section{REFERENCES}

1. Amutha, R.; Gunasekaran, P. (2001). Production of ethanol from liquefied cassava starch using co-immobilized cells of Zymomonas mobilis and Saccharomyces diastatcus. J. Biosci. Bioeng. 92, 560-564.

2. Bai, F. W.; Chena, L. J.; Zhangc, Z.; Andersona, W. A.; Moo-Young, M. (2004). Continuous ethanol production and evaluation of yeast cell lysis and viability loss under very high gravity medium conditions. $J$. Biotechnol. 110, 287-293.

3. Dias, J.C.T.; Rezende, R.P.; Linardi, V.R. (2001). Effects of immobilization in Ba-alginate on nitrile-dependent oxygen uptake rates of Candida guilliermondii. Braz. J. Microbiol. 32, 221-224.

4. Goksungur, Y.; Zorlu, N. (2001). Production of ethanol from beet molasses by $\mathrm{Ca}$-alginate immobilized yeast cell in a packed-bed reactor. Turk. J. Biol. 25, 265-275.
5. Kiyohara, P.K.; Lima, U.A.; Santos, H.S.; Santos, P.S. (2003). Comparative study between yeasts immobilized on alumina beads and on membranes prepared by two routes. Braz. J. Microbiol. 34, 129-137.

6. Miller, G.L. (1959). Use of dinitrosalicylic acid reagent for determination reducing sugar. Anal. Chem., 31, 426-428.

7. Monte Alegre, R.; Rigo, M.; Joekes, I. (2003). Ethanol fermentation of a diluted molasses medium by Saccharomyces cerevisiae immobilized on chrysotile. Braz. Arch. Biol. Technol. 46, 751-757.

8. Najafpour, G.; Younesi, H.; Syahidah, K.; Ismail, K. (2004). Ethanol fermentation in an immobilized cell reactor using Saccharomyces cerevisiae. Bioresour. Technol. 92, 251-260.

9. Ogbonna, J.C.; Tomiyama, S.; Tanaka, H. (1996). Development of a method for immobilization of non-flocculating cells in loofa (luffa cylindrical) sponge. Process. Biochem. 31, 737-744.

10. Ogbonna, J.C.; Tomiyama, S.; Liu, Y.C.; Tanaka, H. (1997). Efficient Production of ethanol by cells immobilized in loofa (Luffa cylindrical) sponge. J. Ferment. Bioeng. 84, 271-274.

11. Ogbonna, J.C.; Mashima, H.; Tanaka, H. (2001). Scale up of fuel ethanol production from sugar beet juice using loofa sponge immobilized bioreactor. Bioresour. Technol. 76, 1-8.

12. Phisalaphong, M.; Srirattana, N.; Tanthapanichakoon, W. (2006). Mathematical modeling to investigate temperature effect on kinetic parameters of ethanol fermentation. Biochem. Eng. J. 28, 36-43.

13. Phisalaphong, M.; Bundiraharijo, R.; Bangrak, P.; Mongkolkajit, J.; Limtong, S. (2007). Alginate-Loofa as carrier matrix for ethanol production. J. Biosci. Bioeng. 104, 214-217.

14. Valach, M.; Navratil, M.; Horvathova, V.; Zigova, J.; Sturdik, E.; Hrabarova, E.; Gemeiner, P. (2006). Efficiency of a fixed-bed and gaslift three-column reactor for continuous production of ethanol by pectate and alginate immobilized Saccharomyces cerevisiae cells. Chem. Pap. 60, 154-159.

15. Vega, J.L.; Clausen, E.C.; Gaddy, J.L. (1988). Biofilm reactors for ethanol production. Enzyme Microb. Technol. 10, 390-402.

16. Wang, B.; Ge, X.M.; Li, N.; Bai, F.W. (2006). Continuous ethanol fermentation coupled with recycling of yeast flocs. Chin. J. Biotechnol. $22,816-821$. 